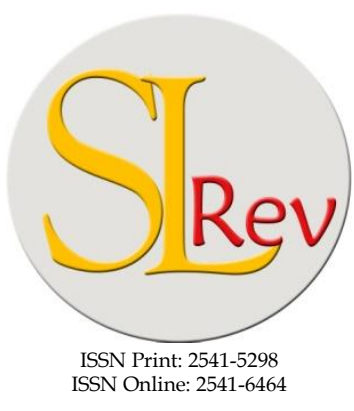

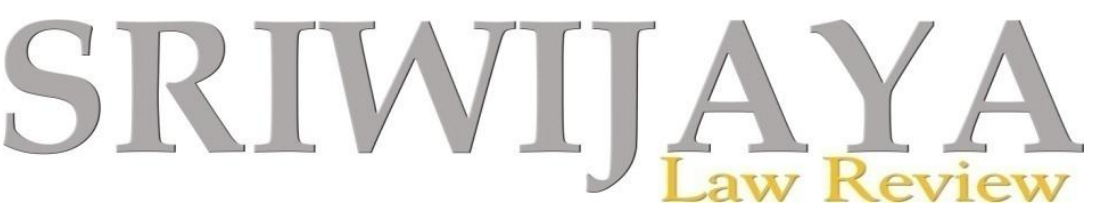

Editorial Office: Faculty of Law, Sriwijaya University Jalan Srijaya Negara, Palembang, South Sumatra 30139, Indonesia. Phone: +62711-580063Fax: +62711-581179

E-mail: sriwijayalawreview@unsri.ac.id| sriwijayalawreview@gmail.com Website: http://journal.fh.unsri.ac.id/index.php/sriwijayalawreview

\title{
RESEARCH-BASED ENVIRONMENTAL LAW: THE DEBATE BETWEEN ECOLOGY VERSUS DEVELOPMENT
}

\author{
Irwansyah
}

\begin{abstract}
Nowadays, economic growth continues to be driven not followed by equity and justice compliance.Cases of natural resources looting, pollution and environmental destruction, forest fires and illegal mining, as well as the neglect of the rights of indigenous peoples, bring into a series of major issues and need study that are not limited to mono-discipline approach, but also to a more important study thatcan be used as a basic study toward a paradigm shift from all stakeholders and policy-makers in this country to synergize the importance of ecological with various dimensions of other interests, such as a fair and equitableeconomic growth, animproving quality of life and welfare of the people. Realizing the balance of ecological and development (economic) interests, have been used a wide variety of approach have been used to improve the environmental management in Indonesia, including command and control, self-regulation, voluntarism, education and information instruments, and economic instruments. These approaches has its weaknesses. These have to be improved. Moreover, as it turns out in pr actice, these efforts needed some more consistent policies in applying the principles of sustainable development for the control and utilization of environmental resources. In addition, strengthening the right to the environmental as a part of human rights, need support of policy-makers toward a paradigm change and a more concrete measures at the level of legislation policy in the field of environmental protection and management that is pro-people and support a judicial decision that is more rational and responsive.
\end{abstract}

Keywords: Development; Ecology; Environmental Law; Natural Resources.

\section{ARTICLE HISTORY:}

Received:

Dec 23, 2016; Reviewed: Dec 30, 2016

Accepted:

Jan 7, 2017; Published: Jan 31, 2017.

Faculty of Law, Hasanuddin University

E-mail: irwansyahrawydharma@yahoo.com

\section{INTRODUCTION}

Conventional development has been successful in increasing economic growth, but also experienced a failure in the aspects of social and environmental. One of the causes for the conventional development put economic on central issues of growth and otherwise put social and environmental factors in a less important position. ${ }^{1}$ Economic 
growth continues to be driven not followed by equity and justice compliance. Many regions have the potential and wealth of abundant natural resources, but ironically the region was just a lot of people who are poor, there is damage and massive environmental pollution, followed by social conflicts in the region. Fundamental mistake against the state and perspectives can be fatal which had a significant impact on the environment.

Various environmental issues that arise and knock the nation and the people who continuously take place without this control,it cannot be conducted through a partial approach alone, but a necessary an integral, comprehensive, and systematic approaches. ${ }^{2}$ Both related to the substance of legislation, strengthening the judiciary, instrument, law enforcement, justice compliance, government authorities, and public participation in it. Cases of natural resources looting, pollution and environmental destruction, forest fires and illegal mining, as well as the neglect of the rights of indigenous peoples, into a series of major issues and need study are not limited to mono-discipline approach, but a discourse to be a study are more intense and in-depth. A research in the field of management and protection of natural resources and environment are not only important to release a concept and new thinking are innovative and correlative to addresses the diversity of problem, but more important to be used as a basic study was a paradigm shift from all stakeholders and policymakers in this country to synergize the im-

1 Emil Salim,Paradigma Pembangunan Berkelanjutan, Jakarta: Kepustakaan Populer Gramedia, 2010, p24.

2 Imam Mulyana, 2016, "The Development of International Law in the Field of Renewable Energy",Hasanuddin Law Review, 2(1), pp38-60. portance of ecological with various dimensions of other interests, such as economic growth are fair and equitable, improved quality of life and welfare of the people.

\section{ANALYSIS AND DISCUSSION}

\section{Environmental Setting Approach}

In relation to the environmental management today, there are at least 6 (six) variations of setting instruments to address environmental problems in Indonesia, namely: (1) command and control regulation, (2) self-regulation, (3) voluntarism, (4) education and information instruments, (5) economic instruments and (6) free market environmentalism. Education and information instruments consist of education and training, corporate environmental reports, community rights to know and pollution inventories, product certification and award schemes. While, economic instruments includes property rights, market creation, fiscal instruments and charge systems, financial instruments, liability instruments, performance bonds, deposits refund system, and removing perverse incentives. ${ }^{3}$

\section{a. Command and Control Approach}

The sixth of instrument variation, then the rule with the command and control approach dominate the environmental management system in Indonesia to date. This is related to more environmental protection through the mechanism of legislation that is command and control, which is characterized by (1) the requirements of specific standards, (2) licensing, and (3) sanctions for offender.

\footnotetext{
Neil Gunningham, et al.,Smart Regulation: DesigningEnvironmental Policy, Oxpord: Clarendon Press, 1998, p38.
} 
The governments' policy in environmental management is done by making laws and other regulations whose contents give a standardized certain target. UUPPLH as an example of laws material indicate the command and control approach.The experience in many developed countries that have implemented this way, it can be concluded that the command and control approach by implementing waste quality standards result in high costs. This condition encourages scientists from various fields working to get a more efficient method to implement pollution environment control.

The policymakers with a variety of strategies are available, allowing serious environmental damage can be slowed, stopped or ideally environment is restored to its original state. One of the most important strategies is environmental regulations. In the broadest sense, the term of environmental regulations include not only conventional forms of command and control regulations, but also includes other forms of public control is more flexible, imaginative, and innovative. For example, self-regulation and coregulation, by involving parties from the business and NGOs and by improving the effectiveness and efficiency of conventional forms of government regulations.

Therefore, environmental regulations need to be redesigned in order to function optimally and meet these criteria above. The main reason is that in a large part of situation, the use of multiple policy instruments and the role of various actors will contains the setting of environmental protection is better than if using a single instrument. A better strategy is to utilize the strengths of each instrument and compensate its weaknesses with the use of additional instru- ments. The combination of these is termed by Neil Gunningham, Peter Grabosky\& Darren Sinclair as Smart Regulation, ${ }^{4}$ which is seen as a new paradigm of wise environmental regulation.

Since the early 1970s, the governments in industrialized countries have responded to the emergence of environmental degradation and industrial pollution with a lot of environmental policies. The dominant government'sresponsesby implementing the rules that is command and control that are designed to prohibit or restrict the activities that damage the environment. Generally, command and control regulations have characteristics of environmental targets, e.g limiting emissions that pollute the water or air, and further sanction if those targets are not achieved.

Based on experience in the application of this command and control approach in many countries, including Indonesia, can be concluded that at least 9 (nine) causes the ineffectiveness of this approach.

First, command and controlinstrument require policy makers have accurate and comprehensive knowledge of the procedures and industrial capacity. For example, in applying the standard of best available technology (BAT), policy-makers are often required to use the information that is lengthy and convoluted to determine the proper pollution reduction targets. There is a clear imbalance of knowledge between policymakers and industry. By assuming that policy-makers acquire the right knowledge, they can only provide a temporary solution for the population, technological, and economic

\footnotetext{
$4 \quad$ Neil,Note 4. p231.
} 
activity, and changes in economic activity and growth, and environmental issues arise.

Second, command and control instruments do not provide an incentive for companies to go beyond the minimum standards that have been set, particularly companies that have invested in pollution control technology to meet the required standard. Inability to encourage companies to go beyond compliance, through process improvement and culture change constantly is one of the most serious failures of command and control traditionally. So, the command and control instruments do not have the ability to encourage companies achieve more than what is required.

Third, command and control instruments in its enforcement are costly and difficult. This is important because it can impact on its reliability. Although in temporer the bodies are not release to enforce, mostly setting regime has not appropriate resources to monitor compliance.

Fourth, command and control instrument are susceptible to political manipulation. Many examples, regulatory policy is hacked for the benefits of individual or groups. Similarly, the regulator has its own interests which may be controlled by a particular industry and do rent-seekingwhich bureaucracy has its own interests to the amount paid at the expense of the public.

Fifth, command and control instruments can lead to complexity of administrative and legal restrictions. The number of environmental laws and regulations related in industrialized countries make it difficult for policy makers and the industry itself to carry out its obligations. Industry became the object of a number of regulations, licens- ing procedures, judgments, and other policies that must be enforced. This can result in excessive regulations and counterproductive. Newcomers in the industry became not-interested due to the regulatory is lengthy and law approval process relating to command and control.

Sixth, command and control instruments are not efficient due to the cost of complianceis great. This inefficiency can be viewed both from the government as policymaker and supervisor as well as businessmen as parties subject to the policy.

Seventh, command and control instruments are rigid. Environmental regulations specify very specific technology standards for the industry. These standards often do not consider the environment and conditions are different among industries, far fewer than the conditions among certain facilities within a single industry. Once set, the standard is difficult to accept changes in technology. Because a technology change is fast, inflexibility of command and control regulations can be more troublesome.

Eighth, many environmental regulations generated by command and control approach has led some experts to conclude that the system will crash due to its own weight is heavy. In accordance with this thinking, many regulations will ultimately lead to both society organized and the legal system reached saturation point. This phenomenon is not run by the inability of the people who arranged for the financial budget necessary to meet the increasing demands of the laws. One of the success of this system is that in twenty-five years ago, members of the community are regulated not only allocate financial resources for achieving compliance, but also include the costs of 
complianceinto their financial plan. Therefore, the community governed have the ability to change from a point of almost zero expenses for the fulfillment, to the point which the expenses for the fulfillment, to a point where the expenses are common in some environmental management in order to obtain a significant advantage.

Ninth, command and controlinstrument does not encourage creativity. Based on this approach, the party governed will do what they have to obey with standard setting, even if this requires the application of new technologies. However, due to financial constraints and the burden of compliance, the parties governed unable or unwilling to seek creative solutions to the problem of pollution.

\section{b. Self-Regulation Approach}

In general, self-regulation approachinvolves industrial organization as opposed to a government or an individual company, which sets the rules and standards regarding the conduct of firms in the industry. The nature and terms of self-regulation principle, as one form of approach to environmental management is participating the community in decision-making arrangements and supervision of environmental management to make people aware of their rights and obligations to participate in decision-making. ${ }^{5}$

This self-regulation approach at least 3 (three) types. First, voluntary or selfregulating in total involving the industry or profession that sets the code of practice, enforcement mechanisms and other mechanisms to regulate them, entirely independent

Otto Soemarwoto,Atur Diri Sendiri: Paradigma Baru Pengelolaan Lingkungan Hidup, Yogyakarta: Gadjah Mada University Press,2004, p176. of the government. Second, must regulate itself directly involving the state, where the community business people to establish control over the behavior itself, but gave details and enforcement to businesses itself, with the approval of the state and/or can be changed if there was a mistake. Third, set self as most of the obligations, the business people themselves are responsible for some specific rules and enforcement, but rule out the setting specification, although no details, which are required by the state.

Meaning of self-regulation is a responsibility to maintain compliance and law enforcement more held by the public. The development of this system in the business world is driven by the stronger and breadth of public pressure on businesses to apply environmentally friendly. To address this threat, they pioneered the growth of new approaches in environmental management which gives the freedom to self-regulate. A company is free to adopt or not a code of conduct. For example, ISO 14000 is issued by the International Standardization Organization (ISO) that isvoluntary. For illegal possession of ISO 14000 certification has great value in the trade competition, many companies who wish to acquire it. Conformity implementation is not supervised by the government, but by a body accredited by ISO.

Basically, this self-regulation approach offers the speed, flexibility, sensitivity to market conditions, greater efficiency, and less government intervention than the existing command and control. This selfregulation can also be viewed as a form of responsive regulation thatis regulation responds to the specific circumstances of the problems faced by the industry. 


\section{c. Voluntarism Approach}

In contrast to self-regulation, which includes social control by the industry association, voluntarism is based on individual companies to run a good thing unilaterally, without any compulsion. In general, voluntarism is initiated by the government and may involve the government running role as coordinator and facilitator. Voluntarism includes agreements voluntarily between the government and individual companies in the form of a contract that is not required as an equal partner, one of them is government. The impetus for action is more likely for their benefit and not for the threat of sanctions.

This approach has 3 (three) elements: (1) depends on voluntary action taken by the private sector, rather than the actions mandated by regulation, (2) the involvement of central government in facilitating the voluntary efforts, and (3) lacked a direct relationship to the requirements of existing law.

\section{d. Educational and Information Strategies Approach}

This fourth Instruments four can be divided into 5 (five) elements: (1) education and training, (2) corporate environmental reports, (3) community right to know and pollution inventories, (4) product certification, and (5) award schemes.

Education and training are essential to change attitudes, behaviors and skills to be consistent with environmental policy. Its importance is to internalize environmental awareness and responsibility into corporate decision-making. Educational instruments can be used to improve management practices.
The second part is a corporate environmental report. The companies have developed a number of management practices in response to the various problems they encounter. One of them is communication with interested parties (stakeholders) for the information regarding the company's own environmental performance.

The third part is the community right to know and pollution inventories. Access to information is an essential requirement for effective public input material into the decision-making environment. Disclosure will invite the public pressure and thereby reduce the burden on the government. To address this, a number of countries have introduced legislation mandating information disclosure on pollution and chemical hazards.

The fourth element is product certification. Eco-label is identifying products to meet the standards set by organizations providing label. It intended to encourage companies to maintain compliance with environmental regulations and provide a framework for business people to improve their environmental performance required by law.

The fifth part is award schemes. This scheme is a potential for publicity, and hence, can contribute to a strategy for education and information on the regulatory regime. Publicity accompanying an award can function to education, raise public awareness of their surroundings, and to focus attention on important issues. Through a system of rewards, good behavior, which may not attract interest, can be published. Award can also be provided by private institutions, such as public interest groups and social organizations, for example the Goldman environmental prize for environmental activities. In Indonesia, the government gave kalpata- 
$r u$ 'sawards with dedication in maintaining the environment.

\section{e. Economic Instrument Approach}

In applying economic instruments, there are some notes to be considered. First, economic instrument is different to voluntary compliance. There is a difference between economic instruments (based on the given of economic incentives for environmental protection efforts) and voluntary compliance (based on the absence of law enforcement, so that compliance be the decision of individual voluntarily). As this opinion, Faure, et.al., argues that economic instruments are based on two things: on the one hand, this instrument is based on the creation of an economic character impetus on compliance; being on the other side of this instrument is based on freedom of pollutant (to determine the level of pollution and how they reach the level of pollution). ${ }^{6}$ Second, economic instruments are not intended as an attempt to reduce or eliminate the government's role in environmental protection. By contrast, economic instruments it requires government intervention from setting, licensing (tradeable permits require permits for acts of pollution, so that only those who have a permit who has a "right" to release emissions), pricing (especially in tax rate arrangement), to the supervision (tax, performance bond, or tradeable permits require effective government oversight).

Thus, in contrast to voluntary compliance, in economic instrument the gov-

\footnotetext{
M. Faure, M. Peeters, and A.G. Wibisana, "Economic Instruments: Suited to Developing Countries?", on M. Faure and N. Niessen (eds.), Environmental Law in Development: Lessons from the Indonesian Experience (Cheltenham: Edward Elgar), 2006, p219.
}

ernment has a very central role. Third, main purposes of economic instruments are internalization and externalities, and not increase state revenues. An effective economic instrument such as environmental taxes, it can be seen from the decline in state revenues of environmenttax; because it indicates that the business people/activity has changed the behavior or process them into eco-friendly activities.

It may be added also that the Indonesian government to use command and control approaches is associated with the substance of legislation in the field of natural resource management and environmental which is characterized by (1) the requirements of specific standards, (2) licensing, and (3) sanction for offender. Even the judicial decision that adjudicate environmental disputes, in general is also strongly influenced by this approach, or a judge who thinks positivist-legalistic.

Interests to increase and improve the region original income is often defeat the interests of environmental protection with the adoption of the Regional Regulation (Perda) which is dominated by the rules on levies, retribution, taxes with this regulation had a negative impact on the environment, and even became the entry point for destruction, pollution, and the depletion of natural resources potential in the region. The autonomy to the regions do not have a positive impact on the improvement and utilization of equitable, sustainable, and wise to the potential of natural resources and environment, even happened many cases in various areas such as abuse of authority against various forms of licensing. In the end, the permissions that serves as a preventive instrument and is expected to be a means of con- 
trol in environmental protection and management became a commodity that was traded by officials in areas that lack of responsibility, integrity, morals, and ethics at the expense of the importance of environmental conservation.

These approaches above have similarity in views with the ideas put by Santosa, who divides broadly 4 (four) types of approaches that can be done, rather than approach through law enforcement, namely: ${ }^{7}$

\section{Command and Control (CAC)} approach;

2. Economic approach;

3. Behavioral approach;

4. Public Pressure approach

The first approach is Command and Control (CAC) approach or ADA aturdanawasiis intended to potential violator is prevented for violation of legislation by means govern, control, and threatened with punishment.

The second is economic approach that departs from the proposition that the party responsible for an activity that has important impact for national environmental nationally considers the implementation of further benefits economically.

The third is a behavioral approach that emphasizes the importance of human motivation through education, cooperation to encourage compliance among others through technical assistance or funding to support compliance programs. The nature of this behavior approach is close cooperation between the governments (regulator) with the object of arrangement.

Mas Achmad Santosa, Good Governance \& Hukum Lingkungan, Jakarta: ICEL, 2001, pp234-235.
The fourth is public pressure approach, providing a space for the community to execute effective supervision and control of the performance of an activity. This approach can be effective if the public is guaranteed the right to express their opinions and objections, right to information, their access to the decision-making process on the existence of an activity, monitoring, and assessment of activities which potential arise impacts for people and the environment.

\section{Sustainable Development}

In the global context, the principle of environmental justice ${ }^{8}$ is an effort of governments in directing development to achieve sustainable prosperity for the community. According to Emil Salim, sustainable development requires a fundamental change from the conventional development, namely: ${ }^{9}$

First, sustainable development changes the short- to long-term perspectives. Basically, conventional development pursues shortterm benefit made through intensive exploitation of natural resources. Not exploitation but enrichment of natural resources that will provide economic benefits, social, and environmental, as well as simultaneously negates the degradation and depletion of natural resources.

Second, sustainable development weakening the dominant position of economic aspects and place them on the same level with social and environment development.

\footnotetext{
8 David Schlosberg, "Three Dimensions of Environmental and Ecological Justice," (Paper presented at Workshop the Nation-state and Ecological Crisis: Sovereignty, European Consortium for Political Research Annual Joint Sessions), 2001, p98.

9 Emil Salim. Note1. p24.
} 
Third, the scale of individual preferences today will be an indicator that determines what items will be produced and through the method of allocation of resources as efficient as possible. Therefore, sustainable development requires a fundamental change of policy that can be placed in the public interest rather than individual, the way is to use fiscal and monetary instruments within a policy framework that is more conducive.

The incidence of disasters and natural in various regions of the country in recent years, and also pollution and destruction of the environment and depletion of natural resources, ${ }^{10}$ as a reason for the failure to apply the concept of sustainable development in a manner of holistic, consistent, and sustainable. This concept has long been introduced by the WCED (World Commissions for Environmental and Development) as a solution to unify the interests of ecology and development.

WCED understand the importance of the legal and institutional changes necessary to switch to the concept of sustainable development, and for that has outlined the actions required at national level to achieve these objectives. ${ }^{11}$

Rio's Declaration on Environment and Development, also called as The Earth Charter contains 27 main principles, some of which becomes an important element in the concept of sustainable development, such as on the substance of Principle 4 which combines the integration between

10 Takdir Rakhmadi,Hukum Lingkungan di Indonesia, Jakarta: PT RajaGrafindo,2015, pp 2-3.

11 Koesnadi Hardjasoemantri, Hukum Tata Lingkungan, 20th ed. Yogyakarta: Gadjah Mada University Press,2009, p15. environmental protection and development (In order to achieve sustainable development, environmental protection shall constitute an integral part of the development process and cannot be considered in isolation from it).

In addition to the characteristic of policy as proposed by Warlan Yusuf below, in the practice of drafting legislation, is also growing tendency patterned liberalcapitalistic or with other terms, legislation regulating the environment management and natural resources is more friendly and permissive toward foreign investment. ${ }^{12}$

a. Establish and strengthen the agencies to protect the environment and manage natural resources.

b. Involve both general public and scientific community in the selection of policy that basically it is complex and difficult from a political view.

c. Improve cooperation between government and industry for advice, assistance, and mutual support in assisting the establishment and implementation of the policies, laws and regulations in order to achieve sustainable industrial development.

d. Strengthen and expand international conventions and agreements which exist to support environmental protection,

12 The official announcement of the fast-train line Jakarta-Bandung by President Jokowi, which is substantially the EIA is incomplete, as a prerequisite for the issuance of Environmental Permit, indicating weakening the sovereignty of the country to foreign investment. The investors enter from China to build a cement plant in Indonesia seem ironic even the Chinese government has banned the establishment of a cement factory with the reasons for their environmental conservation purposes. 
sustainable development, and protection of natural resources.

e. Improving the management of the EIA and the ability to plan resource utilization.

The concept of sustainability use trying to answer a variety of questions about the sacrifice of economic factors and development for the benefit of the environment. This concept focuses on the pattern of development in order to meet current needs without compromising the ability of future generations to meet their needs. ${ }^{13}$

Various courts' decision in Indonesia has also begun to adopt the principle of sustainable development such as the precautionary principle (Principle 15 of the Rio's declaration). One example is the Court's decision of Bandung District Court that known as a case of "Mandalawangi", i.e between Mandalasarivillagers of Garut regency, West Java, against PerumPerhutaniof West Java and the Government. The judges apply the principle 15 of the Rio Declaration or the precautionary principle is to provide the basis for the application of liability (civil) without fault (strict liability or liability without fault). Basically, this type of liability does not require the claimant to prove the existence of the fault of the defendant, along can prove all the elements of damages and causality (cause and effect). ${ }^{14}$

To guarantee the implementation of sustainable development, local governments should facilitate the creation of good envi-

13 Deni Bram, Hukum Lingkungan Hidup: Hompo Ethic Ke Eco Ethic, Bekasi: Gramata Publishing, 2014,p95.

14 Mas Achmad Santosa.Note 8.p 18. ronmental governancethat characterized by 7 (seven) golden rules, namely: ${ }^{15}$

1. Local government must proactively translate and implement environmental legislation, both issued by the central- or local governments through the creation and implementation of local legislation.

2. In implementing development in order to achieve original revenue, local governments should be aware of the limitation of the carrying capacity of ecosystems and sustainability.

3. The government should ensure the empowerment of communities, both in local regulation or decision making relating to the environment management and natural resources in order to guarantee the implementation of sustainable development.

4. Empowering communities can be implemented through transparency in decision-making on environmental management.

5. Local government must guarantee the right of indigenous and local communities in their actions to undertake natural resource management.

6. Local government should ensure and coordinate the harmonization of interests between one sector to another.

7. Local government must proactively enforce the law and local regulation relating to environmental management.

In relation to the field of environmental policy, good governance requires public participation in environmental decision-making and the need for local government apparatus responsive to the needs of society as well as the decision-making process are more trans-

\footnotetext{
15 Sukanda Husin, Penegakan Hukum Lingkungan Indonesia, Jakarta: Sinar Grafika,2009, p18.
} 
parent and accountable so that the embodiment of good environmental governance can be achieved. To establish or toward an embodiment of good environmental governance in a government, we can see how the legislation in the field of natural resources.

Damage to the environment and natural resources is a bad record in the management of natural resources for the sake of development in Indonesia. This condition is caused development and environments are placed at the position opposite each other. Choose development means damage the environment. Instead promote the interests of the environment is inhibiting development and even anti-development. The environment has not been dissolved in the development or environmental interests have not been integrated in the development implementation.

Damage to the environment and natural resources and ecological impact that occurs at the upstream level is actually begins with the development policy and natural resources management did not consider the preservation of the environment. As policies change function and designation of forest areas through the Provincial Spatial changes based on legislation for forestry and spatial planning. Policy changes in the functions and forest areas are then responded to by the local government has a number of authoritiesin natural resources management based on sectoral legislation (mining, forestry, plantation) or under the laws of local government. The spirit of change function (protected forest into production forests) and designation of forest areas (from forest to non-forest/APL) is based on the consideration to be able to access the forest for forest exploitation, mining and plantations for the benefit of the increase in local revenues.

The dominance of the interests of economic development (short-term) against the environmental functions (for the sake of long-term development/ sustainable) are backed up by legislation which puts the interests of each sector of activity so that aspect of cohesion and harmony between laws become neglected, a serious problem that will worsen the condition of the environment and natural resources.

As in the Mining Act No. 4 of 2009 which emphasizes the potential aspect of mineral and/or coal in set mining area. So it can be interpreted that each region containing potential mineral and/or coal can be set into mining area. Protected and conservation areas can be defined as mining area if known to contain potential mineral and/or coal although legislation for forestry and conservation of natural resources and its ecosystem has set the boundaries of protected areas management and conservation which prohibits activities that may threaten life support systems and biodiversity. In the formulation of mining area does not consider the existence of protected and conservation areas as stipulated in the legislation but merely asserts that the mining area is part of the National Spatial Plan.

In the logic of short-term development that emphasizes the promotion of economic growth, the environment tends to be positioned as a provider of natural resources rather than as having a certain carrying capacity limits Policies, plans and programs for environmental degradation control and natural resources by the government (central and local) tend to be "detached" or "separated" from policies, plan and program for regions 
development and sector, not embedded or not-integrated. Or in other words, environmental considerations are not integrated in the process of decision-making.

\section{Right Strengthening for Environmental}

The fourth amendment of the 1945 Constitution in 2002, in addition to confirmation of the constitutionalizationof economic policy, has also formulated new things about the improvement of the status of the environment associated with the human rights are guaranteed by the constitution. ${ }^{16}$ In a further development is often termed environmental constitutionalization in the 1945 constitution.

In another hand that with the provision of Article 28H paragraph (1) of the 1945 Constitution, in Asshiddiqie's view, environmental norms have undergone constitutionalization become the substance of the Constitution as the supreme law. Thus, all policies and actions of government and development should be subject to the provisions concerning human rights on the environment is good and healthy. There should be no more policies contained in the form of laws or regulations under laws that are contrary to the constitutional provisions that pro-environmental. ${ }^{17}$

The amendment of Article 33 the 1945 Constitution on the economy is seen to have assertiveness to managing the relations between economic development and environmental preservation. So the basic principle is that economic development requires harmo-

16 Jimly Asshiddiqie,Green Constitution: Nuansa Hijau UUD Negara Republik Indonesia Tahun 1945, Jakarta: Rajawali Press,2009. p79.

17 Jimly Asshiddiqie. Notes 17. pp 90-91. ny, and synergy with the environmental factor.

Setting environmental rights in legislation, both at the level of laws and local regulations, so far have not shown optimal results as the legal basis for all parties, especially in favor to the public, in the management of natural resources and environment. Similarly, in the hope of law enforcement which reinforces the rights to the environment and local wisdom, is still far from adequate. Law enforcement on the settlement of many environmental cases that damages environment and natural resources is the weakest enforcement. Juridical fact was reinforced by the decision of the Supreme Court and the Constitutional Court has sentenced environmental and natural resources cases as well as on the process of judicial review in the field of water resources management of the provisions in the 1945 Constitution.

In general, legislation governing natural resources in Indonesiahas not shown partiality that is proportional to the aspects of social, economic, political, technological change, and institutional, which will define strategies for natural resources management. The spirit of existing legislation is generally more in favor of economic development (pro-capital) and exploitative, by neglectingthe aspects of social and institutional. Whereas the concepts of governing, the aspect is relatively ignored actually as a main strength to be given a place, in order to achieve sustainable management.

Often, environmental issues are considered only as one of the important sector, but other sectors are policies not in the area of responsibility of the Minister of Environment also should be considered essential. 
In this battle between sectors and agencies, environmental interests, in practice, always lost or defeated by fields, sectors or policies of other agencies, such as mining and energy, forestry and plantations, investment, tourism, and so forth. ${ }^{18}$

The availability of natural resources in quantity or quality is uneven, while the development activities require natural resources is increasing. The development activities also contain the risk of pollution and environmental damage. This condition can lead to the carrying capacity, and environment is declines that eventually become a social burden. ${ }^{19}$

From 12 laws that govern the natural resources, only a few that priority identification proportionally with conservation and pro-people aspects. The spirit of the legislation referred to as the vision and mission is showing only four laws (Agrarian, Conservation of Natural Resources and Ecosystems, Protection and Environmental Management, and Spatial Planning) in their vision and mission show partiality that is proportional to the aspect of conservation and pro-people. $^{20}$

In reaction to the result of development and industrialization has led to environmental degradation and pollution, in the worldwide occurs movement called the deep ecology were performed by many environmental activists. It supposes that the earth with their natural resources to human welfare. There is a negative correlation between the resources endowment a region with an output or re-

18 Jimly Asshiddiqie.Notes 17. p162.

19 Nadia Astriani dan Yulida Adharani, 2016, "Fungsi Izin Dalam Pengendalian Pencemaran Lingkungan", Jurnal Hukum Lingkungan Indonesia, 3(1), p117.

20 Nadia Astrianiand Yulida Adharani.Notes 20.p 43. gion income. This paradigm with the regional autonomy is expected the region to be able to manage the natural resources to the maximum, and take benefits greater. Discussion of law, including research in it, in relation to the natural resources management based on social and economic development must be addressed as part of development concepts. $^{21}$

The linkage between right to building and right to a decent life is evident in some underdevelopment, where poverty encourage the exploitation of natural resources are not sustainable, poverty difficult for the state to set aside the cost of the necessary protection, and poverty influence the level of awareness and community priorities for act as a watchdog, and apply as a consumer who care about the environment (green consumers). Similarly, the development that ignores aspects of environmental protection may result in deterioration of environmental quality, which in turn threatens human life. Therefore, this problem can be bridged with the concept of sustainable development that was popularized by the Brundtland Commission (WCED). ${ }^{22}$

From other that with the provision of Article $28 \mathrm{H}$ paragraph (1) of the 1945 Constitution, in Asshiddiqie's view, environmental norms have undergone constitutionalization become the substance of the Constitution as the supreme law. Thus, all policies and actions of government and development should be subject to the provisions concerning human rights on the environment is good and healthy. There should be no more policies contained in the form of laws or regulations under laws that are contrary to

21 Deni Bram.Note 14. p22.

22 Mas Achmad Santosa.Notes 15. p152. 
the constitutional provisions that proenvironmental. ${ }^{23}$

Fundamental rights are specifically linked to the environment then developing in recent years. The right to a healthy and good environment as stipulated in the constitution is associated with the obligation to protect the environment. This means that the environment with its resources is a common-property that can be used every person, which must be maintained for the benefit of society and for future generations. Environmental protection and its natural resources have a dual purpose, namely to serve public interest as a whole and individuals.

Deterioration of environmental quality is threatened right to life. Right to life is guaranteed in the International Covenant on Civil and Political Rights (Article 4). This is reinforced by Article 9 paragraph (1) of Act No. 39 of 1999 on Human Rights that everyone has right to life, survival, and improve the standard of life. Thus, environmental degradation could result in human rights violations. $^{24}$

Thus, normatively, UUPPLH is suitable or adopt Principle 10 of the Rio's Declaration in 1992 which in principle emphasizes the importance of democratization and public participation in environmental management. $^{25}$

Mas Achmad Santosa.Notes 15.pp90-91.

24 Majda El Muhaj, Dimensi-Dimensi HAM: Mengurai Hak Ekonomi, Sosial, dan Budaya, Jakarta: Rajawali Pers,2008,p204.

25 Principle 10 of the Rio's Declaration, 1992, Environmental issues are best handled with the participation of all concerned citizens, at the relevant level. At the national level. Each individual shall have appropriate access to information concerning the environment that is held by public authorities, including information on hazardous materials and activities in their
According to Siti SundariRangkuti that the rights to a good and healthy environment need to be understood in juridical and realized through legal, as a legal protection for the citizens in the field of environmental. ${ }^{26}$ Protection of human rights, for example, can be implemented in the form of right to take part in the procedure of administrative law, such as participation (inspraak, public hearing) or the right of appeal (beroep) to the administrative rule (decision of the State administration).

The regulation of community involvement as an elementary part of the process of environment democratic is outlined in Article 70 UUPPLH consisting of 3 (three) paragraph and eight (8) points. Among others,governs same rights for the community to play an active role and widest in the protection and management of the environment. This provision, implicitly also governs rights in society, which in principle cannot be separated from the relation to the rights of every person, reflecting the concept of democracy at comprehensive level, because in many cases, communities sometimes limited their role (tends to be passive and formality) in a variety of decision-making which is actually for the benefit of society itself. Examines the role that can be done in the form of community: social supervision, provision of advice, opinions, suggestions, objections, complaints, delivery of information and/or reports, substantially still require further ad-

communicates, and the opportunity to participate in decision making processes. State shall facilities and encourage public awareness and participation by making information widely available. Effective access to judicial and administrative proceeding including redress and remedy, shall be provided.

26 Siti Sundari Rangkuti, Hukum Lingkungan dan Kebijaksanaan Lingkungan Nasional, Surabaya: Airlangga University Press, 2000, p275. 
justment so as not merely procedural juridical, but can touch substantial meaning of its judicial. During this the role of community is only known in relation with the preparation of the right to the environment. Long ago had been confirmed by Santosa ${ }^{27}$ that legal right to the people involved in public decision-making process has been inadequate.

Strengthening of environmental democracy through the strengthening of community rights has become necessary and important to maintain and respect the local wisdom of pluralistic and environmental wisdom that has been underestimated in environmental policy-making. Empowerment of communities in decision-making for the public interest and encourage the use of any information environment is expected to become an important pillar in realizing sustainable development. ${ }^{28}$

Human attitudes and behavior towards the environment is dominated by economic considerations. Economic goals even excessive that encourage over-exploitation without followed by environmental protection measures properly. The attitude and behavior is also affected by the lack of public recognition of the ecological function of the environment which gives service in humans. As a result there was damage to the environment. $^{29}$

\section{Environmental Policy in Indonesia}

In the aspect of policy formulation on the substance of legislation in the field of management and utilization of the environment

\footnotetext{
27 Mas Achmad Santosa, Note24. p55

28 Nomensen Sinamo, Hukum Lingkungan Indonesia, Tangerang: PT Pustaka Mandiri,2010, p51

29 Otto Soemarwoto.Note 6. pp92-93
}

and natural resources for the improvement of social welfare and law enforcement, then there are at least 2 (two) that sometimes does not synergize with each other. First, often a conflict between the interests of ecological and economic, which detrimental to the interests of ecological.Second, the collision of the concern of the government to the corporation and a more accommodating foreign investment compared to strengthen the protection and empowerment, which in turn has triggered many conflicts which are horizontal and vertical. The economy is growing well was not followed by the realization of the concept of equity and environmental justice for every citizen. There is an ironic reality, where regions have abundant natural resources; in fact there are poor people in large. Even in the area was also synonymous with pollution, destruction, and looting massive environments and difficult to control.

To understand the legal policy of environment in Indonesia in detail, need to be described and analyzed more critically and conceptually about the formulation of policies that have been made in the conservation, protection, management, and enforcement of environmental law. Look at the opinion of Asep Yusuf Warlanwho makes classification policies in question, namely: ${ }^{30}$

a. The nature of environmental legislation is still incidental (a rule still reactive and its solutions for short-term purpose, even ad-hoc), commercial (minimum composition of stock for foreign investment in natural resource management achieves 50\%), partial (issues PERPU No. 1 of 2004 which

30 Contained in the book of Deni Bram, Politik Hukum Pengelolaan Lingkungan Hidup, Malang: Setara Press, 2014, pp68-83. 
allow mining in protected forest areas, which had previously been expressly prohibited by Act No. 41 of 1999 on Forestry), sectoral (arrangement by each sector, often arise conflicts of interest, and the potential of disharmony and inconsistency in policy making), and shortcut devices (there is a legal product that is not based on a comprehensive and in-depth assessment).

b. As for the shape of its policies among others; regulatory is policy-integral, regulatory is supporting policy/beyond policy.

Furthermore, understand the views of Lawrence E. Susskind, that there are at least 6 (six) characteristic of successful in formulating environmental policy, that is:

a. Defined a policy problem in a way that was particularly helpful to policy makers;

b. Described the full range of possible policy responses;

c. Overcome resistance to change on the part of the relevant regulatory agency;

d. Provided important opportunities for all stakeholders to participate;

e. Worked to enhance the legitimacy of the particular actions or changes suggested, and;

f. Helped ensure that adequate resources would be available for policy implementation.

In relation to the approaches made to provide reinforcement to the potential contained in the local wisdom, it can be human welfare ecology approach and politicalecology approach. ${ }^{31}$
First, human welfare ecology approach emphasizes that environmental sustainability will not be achieved if not assured of environmental justice, in particular ensuring the welfare of the people. Hence, needs a strategy to implement it. Such strategies by changing the structural framework of laws and political practices of natural resource management, especially more giving opportunities and controls for the regions, local communities and farmers to access natural resources (land, forestry, mining, marine).

Second, the political ecology is an effort to study the causal and effect of environmental changes are more complex than just a biophysical system which concerns the distribution of power within a society. This approach seeks the issues of environmental management (right to environment and environment justice) in which the right refers to the standard requirements/ minimum individual against objects such as the right to life, the right to speak, the right to the environment and others. As for justice emphasize on relational issues between individuals and groups. The concept of the right to environment justice should consider the principles of fairness between intra-generational and intergenerational justice, because the concept of sustainable development emphasizes both dimensions between generations and inter-generational.

Reflect to the environmental wisdom of society with religius-magical characters is concretely crystallized in a legal product of local communities in the definition of law anthropology is called customary law, folk

31 Deni Bram. Note31. p37. 
law, indigenous law, or in the context of Indonesia is called adatlaw/adatrecht. ${ }^{32}$

It is important to re-institutionalize the traditional local wisdom, because it helps to save the environment. Traditional local wisdom has positive function for this community; interestingly it is not defined by a scientific process that uses scientific method both as subjects and objects. ${ }^{33}$

\section{CONCLUSIONS}

To realize the balance of ecological and development (economic) interests, have been used a wide variety of approach to environmental management in Indonesia, includes, command and control, self-regulation, voluntarism, education and information instruments, and economic instruments. As it turns out in practice, however it needed more consistent policies in applying the principles of sustainable development for the control and utilization of environmental resources. In addition, strengthening right to the environmental as part of human rights, need support of policy-makers paradigm change and more concrete measures at the level of legislation policy in the field of environmental protection and management that is pro-people and support a judicial decision are more rational and responsive.

\section{REFERENCES}

Deni Bram. 2014.Hukum Lingkungan Hidup: Hompo Ethic Ke Eco Ethic, Bekasi: Gramata Publishing.

32 I Nyoman Nurjaya, Reorientasi Paradigma Pembangunan Hukum Negara Dalam Masyarakat Multikultural: Perspektif Hukum Progresif. (Paper). Presented on National Seminar on Trisakti University, 15 December 2007, p180

33 Rachmad K. DwiSusilo, SosiologiLingkungan, Rajawali Pers, Jakarta, 2008. p 161.
Deni Bram. 2014.Politik Hukum Pengelolaan Lingkungan Hidup, Malang: Setara Press.

Faure, M. and N. Niessen (eds.), Environmental Law in Development: Lessons from the Indonesian Experience, Cheltenham: Edward Elgar.

Gunningham, Neil., Peter Grabosky, and Darren Siclair. 1998.Smart Regulation: Designing Environmental Policy, Oxford: Clarendon Press.

Hardjasoemantri, Koesnadi. 2009.Hukum Tata Lingkungan, 20th ed. Yogyakarta: Gadjah Mada University Press.

Imam Mulyana. 2016. "The Development of International Law in the Field of Renewable Energy", Hasanuddin Law Review, 2(1).

I Nyoman Nurjaya, Reorientasi Paradigma Pembangunan Hukum Negara Dalam Masyarakat Multikultural: Perspektif Hukum Progresif. (Paper). Presented on National Seminar on Trisakti University, 15 December 2007.

Jimly Asshiddiqie. 2009. Green Constitution: Nuansa Hijau UUD Negara Republik Indonesia Tahun 1945,Jakarta: Rajawali Pers.

Majda El Muhaj. 2008.Dimensi-Dimensi HAM: Mengurai Hak Ekonomi, Sosial, dan Budaya, Jakarta: Rajawali Pers.

Mas Achmad Santosa. 2001.Good Governance \& Hukum Lingkungan, Jakarta: ICEL.

Mas Achmad Santosa. 2016. Alam pun Butuh Hukum \& Keadilan, Jakarta: Asa Prima Pustaka.

Nadia Astriani and Yulida Adharani.2016. "Fungsi Izin Dalam Pengendalian Pencemaran Lingkungan", Jurnal Hukum Lingkungan Indonesia, 3 (1).

Nomensen Sinamo. 2010.Hukum Lingkungan Indonesia, Tangerang: PT Pustaka Mandiri. 
Otto Soemarwoto. 2004.Atur Diri Sendiri: Paradigma Baru Pengelolaan Lingkungan Hidup, Yogyakarta: Gadjah Mada University Press.

Rachmad K. Dwi Susilo. 2008. Sosiologi Lingkungan, Jakarta: Rajawali Pers.

Salim, Emil. 2010. Paradigma Pembangunan Berkelanjutan, Jakarta: Kepustakaan Populer Gramedia.

Siti Sundari Rangkuti. 2005.Hukum Lingkungan dan Kebijaksanaan Lingkungan Nasional, Surabaya: Airlangga University Press.

Schlosberg, David. 2001. "Three Dimensions of Environmental and Ecological Justice," Paper presented at Workshop the Nation-state and Ecological Crisis:
Sovereignty, European Consortium for Political Research Annual Joint Sessions.

Sukanda Husin. 2009.Penegakan Hukum Lingkungan Indonesia, Jakarta: Sinar Grafika.

Takdir Rakhmadi. 2015. Hukum Lingkungan di Indonesia. Jakarta: PT Raja Grafindo.

Tutut Ferdiana Mahita Paksi and Rian Achmad Perdana (Ed.). Penelitian Hukum Inter Disipliner: Sebuah Pengantar Menuju Socio-Legal,Yogyakarta: Thafamedia. 